\title{
Effect of Competencies and Personality on Employee Performance
}

\author{
Rini Nurahaju* Nurul Sih Widanti \\ Faculty of Psychology, Universitas Hang Tuah, Surabaya, Indonesia
}

\begin{abstract}
:
The purpose of this study was to determine the effect of competencies and personality on employee performance. The measurement of competency is carried out using a competency scale designed by researchers based on the theory of Spencer \& Spencer (1993). Personality measurement is carried out using the Big Five theory (McCrae $\&$ Costa) and performance measurement is carried out using theory that developed by Scotter \& Motowidlo (1996). The research subjects were 88 respondents. The data analysis process used multiple regression analysis methods. The result of this study indicates influence of each competency and personality on employee performance. The effective contribution of competencies and personality to performance was $81.6 \%$.
\end{abstract}

Keywords: competencies; personality; performance

DOI: $10.7176 /$ RHSS/10-24-07

Publication date: December $31^{\text {st }} 2020$

\section{Introduction}

A healthy company certainly has good management. All activities which carried out to improve the business of the company or organization are are a form of the company's performance. Employee performance is very important to the success or failure of the company. Good management can be seen from the optimal employee performance. Performance are the results of the work functions or activities of a person or group in an organizational activities to achieve organizational goals. The function of the activities or works referred to the implementation of the results of the work or activities of a person or group which is the authority and responsibility of an organization. The implementation of the work results or work performance is directed to achieve organizational goals within a certain period of time (Tika, 2006). Similar to that, performance is the result of work both in quality and quantity achieved by a person in carrying out a task according to the given responsibility (Mangkunegara, 2010). In short, performance is the result or output of a process (Nurlaila, 2010). When associated with a behavioral approach in management, performance is the quantity or quality of something produced or provided by someone who does the job (Luthans, 2005).

According to Scotter \& Motowidlo (1996) performance is the ability to work or something that is achieved or demonstrated achievement. Performance is an objective reality that can be known and can be observed. Performance includes task performance and non-task performance or contextual performance (Motowidlo, 2005).

According to Koopmans et al (2011) task performance can be defined as the ability in which a person performs his or her job duties. According to Koopmans et al (2011) task performance is one of the dimensions of individual work which has indicators including completing work tasks, work quantity, work quality, work skills, work knowledge, seeking the latest knowledge, working accurately and diligently, planning and organizing, administration, decision making, problem solving, oral and written communication, control and supervision of resources.

Non-task performance or contextual performance includes interpersonal facilitation behavior and job dedication behavior. Interpersonal facilitation behavior is interpersonal oriented behavior that contributes to the performance of organizational goals. It differs from specific jobs from task performance. Interpersonal facilitation behavior includes actions that increase morale, encourage cooperation, remove performance barriers, or help colleagues do the tasks that reffers to their task activities. Thus, interpersonal facilitation includes a variety of interpersonal actions that help maintain the social and interpersonal context needed to support the effectiveness of task performance in the organization.

Job dedication behavior is self-disciplined behavior, which includes following rules, working hard, and taking the initiative to solve problems in the workplace. Job dedication behavior is the basic motivation for performance, which encourages people to act with the intention of promoting the best interests of the organization. Thus, this behavior expresses work dedication, motivation and will traits such as awareness (Borman et al., 1993; Borman et al., 1995; Borman et al., 1991; McHenry et al., 1990 in Scotter \& Motowidlo, 1996), general expectations of task success (Motowidlo, 1979), 1981 in Scotter \& Motowidlo, 1996), and goal orientation (Malouff et al., 1990 in Scotter \& Motowidlo, 1996).

Then what are the factors that affect performance? According to Simanjuntak (2011) a person's performance is influenced by many factors which can be grouped into 3 (three) groups, namely organizational support, management support and individual competencies. According to Steers (in Cahyono, 2005), including : 1. Ability, personality and work interest. 2. Clarity and acceptance or clarity of the role of a worker. 3. Worker's motivation 
level. According to McCormick and Tiffin (in Cahyono, 2005) explained that there are two variables that affect performance, namely individual variables and situational variables. Individual variables consist of experience, education, gender, age, motivation, physical condition, and personality. Situational variables involve two factors, namely: (1) social and organizational factors and (2) physical and occupational factors. Meanwhile, according to Henry Simamora's view (in Mangkunegara, 2010) performance is influenced by three factors: (1) individual factors consisting of abilities and expertise, background, demographics. (2) psychological factors, consisting of perception of attitude (attitude), personality, learning, motivation. (3) organizational factors, consisting of resources, leadership, membership, job design structure. Thus that two things, namely competencies and personality, are internal factors that exist in employees related to performance. What are the role of those two in improving performance? It is important for companies to know those things in order to take related steps to develop the human resources that exist in their company.

The competencies have role to performance. High competencies will result in high performance, and vice versa, low competencies will result in low performance as well. Spencer (in Moeheriono, 2012) explains that the relationship between employee competencies and performance is very close and very important, even if they want to improve their performance, they should have competencies in accordance with their job duties (the right man on the right job). The results of research by Zaim, et.al (2012) showed that competencies has a relationship with performance. Likewise, the research results of Bismark, et.al (2012) showed that competencies has an effect on performance. Performance appraisals for employees are usually based on performance standards that have been prepared by the organization. Thus, the good and bad performance of employees can be seen from their competencies in carrying out work tasks in accordance with their responsibilities. Spencer and Spencer (1993) classify the dimensions and components of individual competencies into three dimensions, namely: (1). Intellectual competencies, (2). Emotional competencies, (3). Social competencies. Intellectual competencies is the character of attitudes and behavior or the will and intellectual abilities of an individual (can be in the form of knowledge, skills, professional understanding, contextual understanding, etc.) which is relatively stable when facing problems in the workplace. Social competencies is a character of attitude and behavior or a willingness to build cooperation with others when facing problems in the workplace. Emotional competencies is the character of attitude and behavior or willingness and ability to control oneself and understand the environment objectively so that the emotional pattern is relatively stable when facing various problems in the workplace.

In organizations, personality plays an important role that affects work behavior. Personality can lead to a desired behavior. This is expressed through attitudes and has an important meaning in organizational behavior, because employees with positive attitudes towards their work tend to produce better performance than employees whose attitudes are neutral or negative towards their work. As time goes by, the theory of personality has developed, one of which is the one introduced by Goldberg in 1981 about the dimension of the Big Five. The big five personality is an approach used in psychology to see human personality through traits arranged in five personality dimensions that have been formed using factor analysis. The five dimensions of personality traits are neuroticism, extraversion, agreeableness, openness, and conscientiousness (Friedman \& Schustack, 2008). McCrae and Costa (in Feist \& Feist, 2009) define personality traits as dimensions of individual differences that tend to show consistent patterns of thoughts, feelings and actions. When describing someone with the "good" trait, this means that the he or she tends to do good at all times and in every situation. This broad definition states that traits can be divided into three main functions: They can be used to summarize, predict and explain a person's behavior, so one reason for the well-known concept of traits is that they provide an economical way to summarize how one person is different from another. . Traits allow a person to make predictions about a person's next behavior. Pervin et al. (2010) explained that personality affects a person's thoughts, feelings, and behavior. The big five refers to the finding that each factor includes a number of more specific traits. Based on some of the explanations above, it can be concluded that the big five personality is an approach in personality psychology that classifies personality traits by analyzing five factors, namely neuroticism, extraversion, openness, agreeableness, and conscientiousness, as well as an unifying explanation of the general system of personality in humans. Personality is one of the factors that most consistently affects performance.

Based on the explanation above, this research hypothesizes: Hypothesis 1: there is an influence of competencies on employee performance; Hypothesis 2, there is an effect of personality on employee performance; and Hypothesis 3, there is an effect of competencies and personality simultaneously on performance.

\section{Methods}

The subjects in this study are 88 employees of a company in Surabaya. Data collected by distributing questionnaires in google form. This form consists of respondent data and three scales used for research data, namely competency scale, personality scale and performance scale. All scales are Likert scale. All items on the scale consist of several favorable items and unfavorable items. Each favorable item has scores ranging from 5-1, while unfavorable item has scores ranging from 1-5. The competency scale created by the researcher contains 21 items, based on the theory of Spencer \& Spencer, namely intellectual competencies, emotional competencies, and 
social competencies. The personality scale using the Big Five theory (McCrae \& Costa) contains 44 items, based on the Big Five Personality aspects, namely Openness, Conscientiousness. Extraversion, Agreeableness, Neuroticism. While the performance scale contains 19 items based on Scotter \& Motowidlo theory, namely aspects of Task performance, Interpersonal Facilitation, Interpersonal, and Job dedication. Hypothesis testing using multiple regression analysis. Multiple regression analysis is a type of statistical test that is used to see the predictive streght of the independent variable (predictor) on the dependent variable (criterion) while the independent variablea are more than one variable.

\section{Results}

The results of the competency scale validity test show all items are valid. The reliability of this scale is indicated by Cronbach's coefficient $\alpha=0.933(\mathrm{~N}=22$ items), so this scale can be said to be very reliable. Meanwhile the personality scale yields 19 valid items and 25 invalid items. The reliability of this scale is indicated by Cronbach's coefficient $\alpha=0.951(\mathrm{~N}=19$ items), so this scale can be said to be very reliable. The results of the performance scale validity test obtained 17 valid items and 2 invalid items. The performance scale has a Cronbach's reliability coefficient of $\alpha=0.938(\mathrm{~N}=17$ items).

The first hypothesis test is used to see how much the independent variable (competencies) affects the dependent variable (employee performance). The results can be shown in the table as follows:

Table 1: Hypothesis Test 1

\begin{tabular}{|l|l|l|l|l|c|c|}
\hline \multicolumn{2}{|l|}{ Model } & Sum of Squares & df & Mean Square & F & Sig. \\
\hline 1 & Regression & 6167.436 & 1 & 6167.436 & 372.895 & $.000^{\mathrm{b}}$ \\
\hline & Residual & 1422.382 & 86 & 16.539 & & \\
\hline & Total & 7589.818 & 87 & & & \\
\hline
\end{tabular}

Based on table 1, it can be seen that the significance value in the ANOVA table is $0,000<0.05$, so it can be concluded that the regression coefficient value is significant, which means that the independent variable, namely competencies, has a significant effect on the dependent variable, namely performance. The magnitude of the influence of competencies on employee performance is shown by the value of $\mathrm{R}$ Square in the model summary table as follows:

Table 2: R Square Hypothesis Test 1

\begin{tabular}{|c|c|l|l|l|}
\hline Model & R & R Square & Adjusted R Square & Std. Error of the Estimate \\
\hline 1 & $.901^{\mathrm{a}}$ & .813 & .810 & 4.067 \\
\hline
\end{tabular}

Based on table 2, it can be seen that the value of R Square is 0.813 . Thus it can be concluded that the influence of the competency variable on employee performance is $81.3 \%$.

The second hypothesis test is used to see how much the independent variable (personality) affects the dependent variable (employee performance), and it can be shown in the table as follows :

Table 3: Hypothesis Test 2

\begin{tabular}{|l|l|l|l|l|l|c|}
\hline \multicolumn{2}{|l|}{ Model } & Sum of Squares & df & Mean Square & F & Sig. \\
\hline 1 & Regression & 4311.574 & 1 & 4311.574 & 113.108 & $.000^{\mathrm{b}}$ \\
\hline & Residual & 3278.244 & 86 & 38.119 & & \\
\hline & Total & 7589.818 & 87 & & & \\
\hline
\end{tabular}

Based on table 3 , it can be seen that the significance value in the ANOVA table is $0.000<0.05$, so it can be concluded that the regression coefficient value is significant, which means that the independent variable, namely personality, has a significant effect on performance.as the dependent variable.

The magnitude of the influence of the personality variable on performance is shown by the R Square value in the model summary table as follows:

Table 4: R Square Hypothesis Test 2

\begin{tabular}{|c|c|c|c|c|}
\hline Model & $\mathrm{R}$ & $\mathrm{R}$ Square & Adjusted R Square & Std. Error of the Estimate \\
\hline 1 & $.754^{\mathrm{a}}$ & .568 & .563 & 6.174 \\
\hline
\end{tabular}

Based on table 4, it can be seen that the R Square value shows 0.568. Thus it can be seen that the influence of personality variables on performance is $56.8 \%$.

The third hypothesis test is used to see how much the independent variables (competencies and personality) jointly affect the dependent variable (employee performance), it can be shown in the table as follows:

Table 5: Hypothesis Test 3

\begin{tabular}{|l|l|l|l|l|l|c|}
\hline \multicolumn{2}{|l|}{ Model } & Sum of Squares & df & Mean Square & F & Sig. \\
\hline 1 & Regression & 6191.147 & 2 & 3095.574 & 188.124 & $.000^{\mathrm{b}}$ \\
\hline & Residual & 1398.671 & 85 & 16.455 & & \\
\hline & Total & 7589.818 & 87 & & & \\
\hline
\end{tabular}

Based on table 5, it can be seen that the significance value in the ANOVA table is $0.000<0.05$, so it can be concluded that the regression coefficient value is significant, which means that together the independent variables, 
namely competencies and personality, have a significant effect on the dependent variable, namely employee performance.

The magnitude of the influence of the competency and personality variables is shown by the R Square value in the model summary table as follows:

Table 6: R Square Hypothesis Test 3

\begin{tabular}{|l|c|l|l|l|}
\hline Model & $\mathrm{R}$ & $\mathrm{R}$ Square & Adjusted R Square & Std. Error of the Estimate \\
\hline 1 & $.903^{\mathrm{a}}$ & .816 & .811 & 4.056 \\
\hline
\end{tabular}

Based on table 6 , it can be seen that the $\mathrm{R}$ Square value shows 0.816 . Thus it can be seen that the magnitude of the influence of the competency and personality variables together on employee performance is $81.6 \%$.

\section{Discussion}

This study is intended to determine the effect of competencies on employee performance, the effect of personality influence on employee performance and the effect of competencies and personality together on employee performance. The results of data analysis show that all hypotheses in this study are accepted.

Based on the results of the data analysis, it is known that there is an influence of competencies on performance by $81.3 \%$. The results of this research are in line with Spencer \& Spencer (in Moeheriono, 2011) that there is a very close relationship between competencies and performance. The results of this study also support the previous research conducted by Rizal et al. (2013) using the SEM test, that competencies is the main factor affecting performance (path coefficient 0.81), with attachment reinforcement factors (path coefficient 0.78 ) and supporting factors of motivation (0.66) and job satisfaction (path coefficient 0.65). Research conducted by Kartika and Sugiarto (2014), shows that the competencies of office administration employees has a significant effect on performance. Research conducted by Rokhayati (2017) also found that soft skills as part of competencies proved to have a positive and significant effect on employee performance at PT. Krakatau Tirta Industri. Martini's research (2018) with the PLS SEM test resulted in the finding that the competencies of woven cloth employees in Bali with a total of 112 respondents had a significant effect on performance. Research conducted by Hakim (2015) in educational setting using multiple regression tests shows that partially pedagogical competencies, personality competencies, professional competencies and social competencies have a significant influence in increasing learning achievement. In more detail, the contribution of the percentage aspect of competencies shows that intellectual competencies is $43 \%$, social competencies is $35 \%$ and emotional competencies is $22 \%$.

The results of this study explain that intellectual competencies is the most dominant. The results of this study explain that intellectual competencies is the most dominant. individual social competencies is internalized in the form of employees who are sufficiently able to convince and influence others, have enough organizational awareness, sufficiently capable of building work relationships, can develop others, can direct subordinates, can work in teams, and sufficiently capable of leading groups. Meanwhile, individual emotional competencies is internalized in the form of adequate mutual understanding, relatively good self-control, good self-confidence, relatively adaptable, and has a high enough commitment to the organization.

Besides competencies, the results of the study also show that personality affects employee performance by $56.8 \%$. The aspects contained in this personality are related to the individual's performance. The results of this study are in line with the results of Furnhama's (1999) research which found that personality (big five) affects performance. The results of Moscoso's (2004) study indicate that a personality style characterized primarily as neurotic shows a relationship with each criterion. Shyness, sadness, pessimism, egocentricity correlate with task performance, contextual performance, and overall job performance. The magnitude of correlation ranges from 0.24 to 0.35 for performance tasks, ranges from 0.27 to 0.43 for contextual performance, and ranges from 0.27 to 0.45 for overall job performance. Widyasari's (2007) research found that personality has an effect of $33.4 \%$ on performance. the research of Blicke et al (2008) shows that the personality (big five) of 610 people who work 12 hours a week affects their performance. Other research held by Kramer (2014) shows that in tasks that require different skills and low interdependence among group members, differences in extraversion will result in better group performance, whereas in tasks characterized by maximum interdependence, the level of neuroticism higher will result in lower group performance. Based on research held by Nasyroh and Wikansari (2017), the results of the Pearson correlation between personality (Big Five Personality) and the performance of employees of PT. Indonesian Trading Company HCM division, procurement, sales and general, amounted to 0.362. Meanwhile, the research conducted by Kosegeran et al (2019) showed that there was a relationship between personality types and the performance of nurses in the inpatient room at GMIM Bethesda Tomohon Hospital.

Meanwhile, from the analysis of the aspects that forms personality variables, the agreeableness got the highest percentage $(32 \%)$, then followed by conscientiousness with the percentage of $26 \%$, neuroticism $(22 \%)$, openness $(11 \%)$ and the lowest percentage is extraversion (10\%). The aspect of agreeableness can be described that employees are able to adapt well socially, friendly, always give in, avoid conflict and have a tendency to follow other people. In the aspect of conscientiousness or also known as lack of impulsivity, employees are generally very careful, reliable, orderly and responsible. While the neuroticism aspect, it is described as having negative 
emotions such as worry, anxiety, insecurity, and instability. They have relatively difficult relationship and commitment. In openness, which is closely related to openness of insight and originality of ideas, they are happy with new information, and also refers to how employees are willing to make adjustments to a new idea or situation. In the extraversion aspect, it relates to the level of comfort in a relationship.

The results of this study also found that competencies and personality have an influence on performance. If the factors of competencies and personality are combined together, they have an effective contribution to performance by $81.6 \%$. This shows that employee performance is strongly influenced by these two complementary factors. Each of these factors has a significant contribution, but when combined, the two of them really have a very significant role. This is also consistent with research conducted by Alfian et al. (2018) on PLN employees in the Pasuruan area, where the effective contribution of the two factors, namely competencies and personality to performance, is $47.6 \%$.

The performance factor shows that job dedication is the aspect with highest percentage (42\%). While the task performance aspect and the interpersonal facilitation behavior aspect had the same percentage, that is $29 \%$ each. This shows that employees have high self-discipline, including following rules, working hard, and taking the initiative to solve problems in the workplace. They do the main job well. Apart from that, it also acts that increases morale, encourages cooperation, seeks to remove performance barriers, and helps colleagues do work that is oriented towards their task activities.

\section{Conclusion}

Partially employee competencies have a significant effect on employee performance by $81.3 \%$. Employee personality has a significant effect on employee performance by $56.8 \%$. Simultaneously the competencies and personality of employees have a significant effect on employee performance by $81.6 \%$. This shows that competencies and personality have an effect on employee performance. While the remaining $19.4 \%$ is influenced by other factors which are not examined.

\section{Suggestion}

Based on the results of this research, companies can take advantage of information to be used as data to develop human resources in the company. For employees. can be information that can be used as an evaluation to develop himself in order to achieve the optimization of himself and what the company wants. For future researchers, it is expected that it will become a reference for previous research related to the concept of competencies, personality and performance.

\section{REFERENCES}

Alfian, Y., Musadieq, MA., Sulistyo, MCW. (2018) Pengaruh Kepribadian Dan Kompetensi Terhadap Kinerja Karyawan (Studi Pada Karyawan PT PLN (Persero) Area Pasuruan). Jurnal Administrasi Bisnis. 58 (2)

Bismark, et.al, (2012). Pengaruh Kompetensi dan Desain Pekerjaan Terhadap Kinerja Pegawai Negeri Sipil pada Kantor Bupati Solok Selatan. Jurnal Administrasi dan Kebijakan Publik, Vol.1 No.2.

Blickle, G., Meurs, JA., Zettler, I., Solga, J., Noethen, D., Kramer, J. Ferris, GR (2008) Personality, political skill, and job performance. Journal of Vocational Behavior 72,pp 377-387

Cahyono, B. \& Suharto (2005). Pengaruh Budaya Organisasi, Kepemimpinan dan Motivasi Kerja Terhadap Kinerja Sumber Daya Manusia Di Sekretariat DPRD Propinsi Jawa Tengah. Jurnal JRBI Yogyakarta.

Feist, J. \& Feist, G. J. (2009). Teori Kepribadian (Theories of Personality). Edisi Ketujuh. Jakarta Selatan: Salembada Humanika.

Friedman, H. S.\& Schustack, M. W. (2008). Kepribadian Teori Klasik dan Riset Modern Jilid 1. Jakarta: Erlangga

Furnhama, A., Jackson, CJ., Miller, T. (1999) Personality, learning style and work performance. Personality and Individual Differences. 27, pp 1113-1122

Hakim, A. (2015) Contribution of Competencies Teacher (Pedagogical, Personality, Professional Competencies and Social) On the Performance of Learning. The International Journal Of Engineering And Science 4 (2) pp 01-12 (p): $2319-1805$

Kartika, L. N., \& Sugiarto, A. (2014). Pengaruh tingkat kompetensi terhadap kinerja pegawai administrasi perkantoran. Jurnal Ekonomi dan Bisnis, 17(1), 73-90.

Koopmans, L., Bernaards, C.M., Bernaards, V.H., Schaufeli, W.B., Vet, H.C.W., Beek, A.J. (2011). Conceptual frameworks of individual work performance a systematic review. American College of Occupational and Environmental Medicine, 53(8)

Kosegeran, M. G., Pangemanan, D. H., \& Hamel, R. S. (2019). Hubungan Tipe Kepribadian Dengan Kinerja Perawat Di Ruangan Rawat Inap Rsu Gmim Bethesda Tomohon. Jurnal Keperawatan, 7(1).

Kramer, A., Bhave, DP., Johnson, TD.(2014). Personality and Group Performance: The Importance of Personality Composition and Work Tasks. Personality and Individual Differences. 58, 132-137. Research Collection Lee Kong Chian School Of Business. 
Luthans, F. (2005). Organizational Behavior. New York: McGraw-hill.

Mangkunegara, AA. (2010). Manajemen Sumber Daya Manusia Perusahaan. Bandung: PT Remaja Rosdakarya

Martini, IAO., Rahyuda, IK., Sintaasih. DK., Piartrini, PS.(2018) The Influence of Competency on Employee Performance through Organizational Commitment Dimension. Journal of Business and Management .20, (2), pp 29-37 DOI: 10.9790/487X-2002082937

Moeheriono (2012). Pengukuran Kinerja Berbasis Kompetensi. Surabaya, Ghalia.

Moscoso, S., Salgado, JF. (2004) “Dark Side”' Personality Styles as Predictors of Task, Contextual, and Job Performance. International Journal Of Selection And Assessment. 12 (4) pp 356-362

Motowidlo, S.J. (2005) Job performance: Handbook of psychology. Vol 12- Industrial and Organizational Psychology- John Wiley \& Sons, Inc

Nasyroh, M., \& Wikansari, R. (2017). Hubungan Antara Kepribadian (Big Five Personality Model) dengan Kinerja Karyawan. Jurnal Ecopsy, 4(1), 10-16.

Nurlaila. (2010). Manajemen Sumber Daya Manusia I. Penerbit LepKhair.

Tika, MP (2006). Budaya Organisasi dan Peningkatan Kinerja Perusahaan, Cetakan Pertama, PT. Bhumi Aksara, Jakarta.

Pervin, et al. (2010). Psikologi Kepribadian: Teori dan Penelitian. Jakarta: Kencana (Edisi Kesembilan).

Rizal, Y., Hubeis, M., Mangkuprawira, S., \& Maulana, A. (2013). Pengaruh faktor kompetensi terhadap kinerja individu di perusahaan agroindustri go public. Manajemen IKM: Jurnal manajemen pengembangan industri kecil menengah, 8(1), 1-8.

Rokhayati1,A., Kambara, R., Ibrahim, M. (2017) Pengaruh Soft Skill Dan Perencanaan Karir Terhadap Kinerja Karyawan Dengan Kualitas Pelatihan Sebagai Variabel Moderator (Studi Empiris Pada Pt. Krakatau Tirta Industri Cilegon) Jurnal Riset Bisnis Dan Manajemen Tirtayasa (Jrbmt), Vol. 1 (2) 107-124

Scotter, J.R.V., \& Motowidlo, S.J. (1996). Interpersonal facilitation and job dedication as separate facets of contextual performance. Journal Of Applied Psychology, 81(5), 525-531.

Simanjuntak, PJ (2011). Manajemen Evaluasi Kinerja. Edisi 3. Jakarta. Fakutas UI

Spencer, L.M. , Spencer, S.M. (1993). Competencies at Work: Models for Superior Performance. Wiley Publisher

Widyasari, R., Syahlani, Sp. Dan Santosa, Ka (2007) Pengaruh Kepribadian Terhadap Kinerja Karyawan Berpendidikan Tinggi : Analisis Pada Perusahaan Peternakan Di Jawa Tengah Dan Daerah Istimewa Yogyakarta. Kinerja. 11 (1)

Zaim, et.al (2013). Analysing The Effects of Individual Competencies on Performance : a field Study in Service Industies in Turkey. Journal of Global Strategic Management, No.14, December. 